\title{
Preliminary Research on Second Language Teaching Reform In Foreign Language Postgraduates
}

\author{
Yan LIU \\ College of Foreign languages of Tianjin Polytechnic University, Tianjin, China
}

liuyan@tjpu.edu.cn

Keywords: foreign language postgraduates; second foreign languages; exploration on teaching reform.

\begin{abstract}
This paper mainly discusses the second language courses of graduate education curriculum system for foreign language postgraduates. Its development should comply with the demand of the times and be promoted from the following five aspects: (1)Establish the training objective of second language courses for foreign language postgraduates under new circumstances. (2)Choose practical teaching materials to cultivate students' ability to use language.(3)Allocate reasonable teaching time to ensure the training objectives are meeted.(4)Adopt flexible teaching models to improve teaching efficiency.(5)Employ reasonable assessment methods to evaluate students' ability to use second foreign languages.
\end{abstract}

\section{Introduction}

With the rapid development of China's economy and economy globalization, minor language talents are urgently needed here, which, however, cannot be satisfied by current professional teaching and training. Therefore, the teaching of second foreign language (minor languages) in higher institutions may become a necessary supplement. Nevertheless, the second foreign language teachings in higher institutions of China are not satisfactory and teaching objectives cannot be fully realized. Under such circumstances, second foreign language teaching faces both with opportunities and challenges. The reform on curriculum and second foreign language teaching will meet the need of economic development and foreign language course construction, satisfy the demand for minor language talents and promote the long-term development of second foreign language teaching. Therefore, it's high time promote the construction of second foreign language course for second foreign language postgraduates. This paper explores the objective of talents training, teaching contents, selection of teaching materials, teaching model, teaching time allocation and teaching evaluation system, which will serve as a modest spur to induce colleagues' valuable opinions.

The Construction of the Second Foreign Language Course for Majoring In Foreign Languages Should Conform to the Needs of the Times and Start From the Following Five Aspects

\section{Construct the Second Foreign Language Training Target for Postgraduates Majoring in Foreign Language in the New Situation}

\section{Analysis of the Second Foreign Language for postgraduates majoring in Foreign Language}

To fully understand and analyze teaching objects is the prerequisite for constructing a reasonable second foreign language training goal for graduate students. The second language courses for postgraduates majoring in Foreign Language usually offer for those who have studied two years at undergraduate level. Students at the undergraduate level have basic knowledge of second language grammar and a certain amount of vocabulary and sentence patterns. Their second language is about level 3. However, most students' second language listening and speaking ability is still weak. In addition, for English majors, English has already become its major, and then acquiring a foreign language may broaden the exchange and research path in its field of specialization. At the same time, compared with other majors whose first language is English, most postgraduates of English 
major do not have obvious advantages when choosing careers, so the mastery of the second degree is even more important.

\section{Analysis of Employment Status}

With the intensification of global economic integration and the increasing international status of China, trade cooperation and cultural exchanges have become increasingly frequent. Many enterprises and companies have been abroad one after another, and more and more foreign talents are required. In comparison with English, the minority language talents will be more exuberant, with English plus minority language talents may have more advantages in career. The Chinanews pointed out at June 27th, 2014 the minority language talents demands doubled favored in career "Since 2005, the Chinese job market has doubled the demand for professionals specializing in Japanese, French, German and Spanish. According to statistics from the Employment Guidance Center of the Ministry of Education in 2012, the employment rate of minority language specialists in Russian, German, French, Spanish and Arabic is more than 85\%.... As the pace of China's 'going out' and 'bringing in' gradually expand, the stage for minor language talents will also become broader and more enviable as the 'Gold-Collar ' class."

\section{What's the Preception to Goal of the Second Foreign Language Training for Foreign Language Graduate Students during the Period of Graduate Study is to "Pick Up" Their Second Foreign Language.}

That means strengthening their ability of listening speaking reading and writing on the basis level of their second foreign language to meet the standard of College Foreign Language Test Band 4 or above so that they can deal with French daily affairs and towards the direction of being the talent of the first, the second foreign language. In this way, they could have both the professional level of the first foreign language and the competitive of the second one which will takes an obvious advantage in their future career or personal professional ability.

\section{Choose Practical Teaching Materials to Cultivate Students' Ability of Linguistic Performance}

Textbooks are the materials for teachers and students, and the selection of appropriate ones play a decisive role in making the course teaching go with a wheel. And as for foreign language teaching, textbooks are particularly important. In the selection of textbooks, teacher should consider the emphasis of the compilation of teaching materials, as well as the practical situation of the teaching objects. For example, English major graduate students have mastered the basic knowledge of grammar and common vocabulary through undergraduate Russian learning as the second foreign language, but their listening, speaking and writing ability is relatively poor, so teachers should select textbooks focus on cultivating students' ability of listening, speaking and writing as teaching materials during the postgraduate stage, this can be really "treat pupils as individuals" and "shoot the arrow at the target" which improve the students' listening speaking and writing ability and realize the training goal of Russian as the second foreign language.

\section{Allocating the Teaching Time Rationally to Achieve the Training Objectives of English Postgraduates for Learning the Second Foreign Language}

The allocation of teaching time depends on the textbooks and target students. It is guaranteed for English postgraduates to the training goal.

As stated above, through the survey and analysis on the real level of postgraduates, postgraduates have grasped the basic grammar, memorized an elementary vocabulary, and had a strong reading and comprehensive ability, but most of them have the poor ability of listening, speaking and writing. Therefore, it is a must for teachers to instruct them to proficiently master the grammar of the second language while to improve their listening, speaking and writing ability. 


\section{Adopting the Flexible Teaching Methods to Improve the Classroom Teaching Efficiency}

Teaching models should be varied for students, teaching materials and training objectives of the second language at each class.

\section{The Application of Teaching Methods:}

Teachers should combine traditional teaching method and modern audio-visual teaching method instead of "cramming education" to arouse the enthusiasm of students fully by actively engagement in Russian leaching.

\section{Giving Full Play to Their Own Advantages for Specific Students.}

English postgraduates excel in English learning, so it is better for teachers to make comparisons between English and the second foreign language when teaching, which will contribute to their studying the second foreign language with ease.

\section{Take A Reasoning Appraisal Method And Examine The Capability of The Students' Second Foreign Language In All Respects}

The teaching goal of the second foreign language for the graduate student is to cultivate the applied talents with both the basic knowledge of second language and a certain communicative ability in the second foreign language. Therefore we should take that point to the full consideration in the assessment method of the course examination and at the same time, we should also take into account the objective situation of the second language teaching for graduate students in order to offer them a comprehensive examination.

\section{Conclusion}

The reform on curriculum and second language teaching for foreign language postgraduates will meet the need of economic development and foreign language course construction, satisfy the demand for minor language talents and promote the long-term development of second language teaching. The author's thinking and research on the second language curriculum construction for foreign language postgraduates are that, in order to meet the need of the times, this paper puts forward the conception of second language curriculum from the aspects of the objective of talents training, teaching contents, selection of teaching materials, teaching model, teaching time allocation and teaching evaluation system, which aims to promote the teaching and learning of second language, improve the effect and quality of the second language teaching, and enable English postgraduates to benefit from "second language" in choosing jobs or improving their professional abilities.

\section{References}

[1] Yin Qin. Modern Teaching Method for Foreign Languages [M]. Central Compilation \& Translation Press, 2009, 6.

[2] Ying Yuntian. Foreign language teaching method [M]. Higher Education Press, 2002, 2.

[3] Wang Xiuli. Curriculum Reform for French Majors at BLCU [J]. Journal of Language and Literature Studies (higher education, Foreign Language Edition), 2008, 2.

[4] Xie Anban. On the construction of a reasonable curriculum system of graduate education [J]. Journal of Higher Education, 2003, 5.

[5] Sheng Weidan. The practice and reflection of the second foreign teaching of postgraduates [J]. Higher Agricultural Education, 2001, 5. 
[6] Tang Xiaoqing. Minority language talent demand grows exponentially into the employment [DB/OL].http://www.chinanews.com/edu/2014/06-27/6329193.shtml 2014-06-27 22:41:16. 